\title{
Tumor-Associated Process
}

National Cancer Institute

\section{Source}

National Cancer Institute. Tumor-Associated Process. NCI Thesaurus. Code C21188.

An event, process, or condition that supports, or results from, tumor development. 